\title{
Extracellular Space
}

National Cancer Institute

\section{Source}

National Cancer Institute. Extracellular Space. NCI Thesaurus. Code C26055.

Interstitial space between cells, occupied by fluid as well as amorphous and fibrous substances. 